\title{
NÁLEZY KERAMIKY Z OBRANNÝCH PRIEKOP MESTA ŽILINA
}

\author{
SAMUEL ŠPANIHEL
}

\begin{abstract}
Abstrakt: V tomto príspevku je prezentovaný výskum, ktorý prebiehal v meste Žilina na prelome rokov 2005 a 2006 na Ulici J. M. Hurbana. Jeho výsledky sa dotýkajú stále otvorenej otázky žilinskej archeológie, ktorou je fortifikácia mesta, pretože na skúmanej ploche boli odhalené priekopovité objekty, ktorých poloha, vel'kost' a orientácia dovol'uje predpokladat' ich obranný charakter. Najpočetnejšiu skupinu nálezov predstavuje keramika, ktorá sa dá rozdelit' na kuchynskú, stolovú a kachliarsku. Z tohto dôvodu sa tento príspevok zameriava najmä na n̆u, ako hlavného nositel'a informácií.
\end{abstract}

Kl'účové slová: stredoveké mesto - opevnenie - keramika - severozápadné Slovensko.

\section{Pottery Finds from Defensive Ditches in the Town of Žilina}

Abstract: This contribution presents the outcome of research carried out in the town of Žilina in Ulica J. M. Hurbana Street in 2005-2006. The results concern a still-open issue of Žilina archaeology, i.e. the fortification of the town. Ditch-type features were excavated in the investigated area; their location, dimensions and orientation point to a defensive character. Pottery makes up the largest group among the finds, and can be divided into kitchenware, tableware and tiles. The article thus centres on pottery as the main source of information.

Key words: medieval town - fortification - pottery - north-western Slovakia.

\section{Doterajšie poznatky o opevnení mesta}

Mesto Žilina leží v Žilinskej kotline, ktorá sa nachádza na severozápadnom Slovensku pri hranici s Českou a Pol'skou republikou a je situované na severozápadnom okraji kotliny pri sútoku Kysuce a Rajčianky s Váhom.

Základom mesta bolo pravdepodobne zoskupenie slovanských osád z 10. až 13. storočia, lokalizované na širšom území dnešného mesta. V ich pomyselnom strede, v Žiline-Dolných Rudinách, stojí románsky Kostol sv. Štefana krála, ktorý mal vzniknút' najneskôr v 40. rokoch 13. storočia (Marsina 1975, 36). Prvá písomná zmienka o meste, respektíve o vyššie spomínanom komplexe osád - terra de Selinan - územie Žilina, či skôr Žiliňany, je v listine z roku 1208, ktorá obsahuje zoznam majetkov nitrianskeho biskupstva. Terra de Selinan sa spomína ako územie ležiace už za severnou hranicou daného cirkevného regiónu (Prikryl-Štanský 1996, 1). Toto osídlenie zaniká alebo je silne zdecimované prepadom komesa Štefana na Vel'konočný pondelok, a to bud' v roku 1270 (Marsina 1975, 36), alebo až v roku 1280 (Prikryl-Štanský 1996, 2).

Koncom 13. storočia sa na území dnešného historického jadra usádzajú sliezski Nemci, pravdepodobne z Těšínska. Do tejto doby spadá i prvá fáza výstavby Kostola Najsvätejšej Trojice a ustanovenie žilinskej farnosti (Prikryl-Štanský 1996, 2).

V roku 1302 sa Žilina stáva majetkom Matúša Čáka Trenčianskeho. Dvadsiateho tretieho apríla roku 1312 je Žilina prvýkrát spomínaná ako civitas, podl’a ktorého práv sa má riadit' obec Kolárovice (Prikryl-Štanský 1996, 2). Z roku 1318 pochádza prvá písomná zmienka o žilinskom hrade, ktorý je stále predmetom odborných diskusií (Repková 2012, 105). V roku 2008 boli $\mathrm{v}$ tesnej blízkosti parcely, na ktorej prebiehal v tomto príspevku prezentovaný výskum, objavené základy mohutnej stavby s kruhovým pôdorysom. Táto budova bola neskôr identifikovaná ako žilinský hrad (Hoššo-König-Šuteková 2011, 105-106; obr. 1). Podl’a dochovaného masívneho pôdorysu sa predpokladá, že hrad predstavovala najmä valcovitá veža, typologicky označovaná ako donžon (Repková 2012, 105). Čast' vedeckej obce však predpokladá, vzhl'adom na blízkost' stredovekej priekopy a absenciu d’alších funkčných častí hradu, že zachytené základy predstavujú iba vežu, ktorá bola súčastou opevnenia mesta (Repková 2012, 109). 


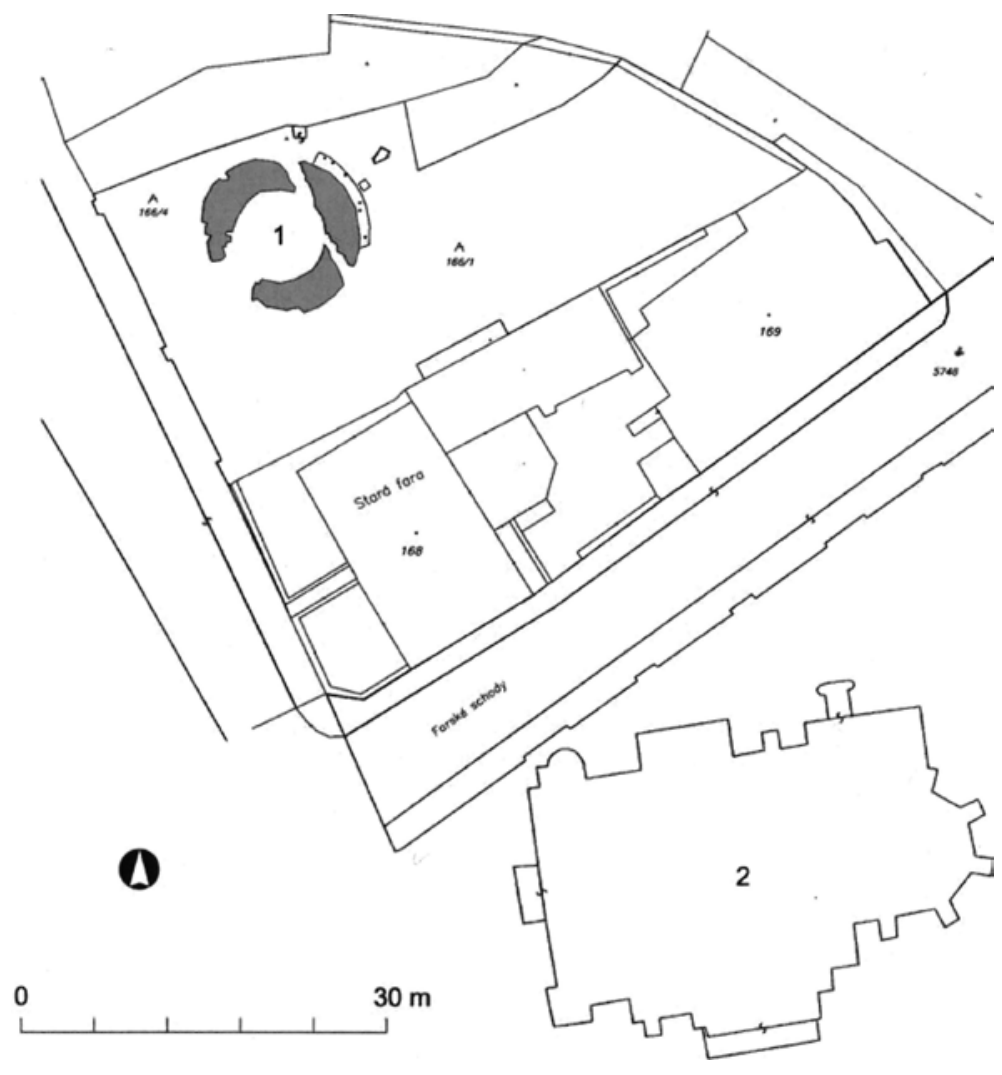

Obr. 1. Žilina, historické centrum. Situovanie kruhovej veže. 1 - valcovitá veža, 2 - farský Kostol Najsvätejšej Trojice. Podl’a Repková 2012, 106, obr. 1 .

Abb. 1. Žilina, historisches Zentrum. Lage des Rundturms. 1 - zylinderförmiger Turm, 2 - Dreifaltigkeitskirche. Nach Repková 2012, 106, Abb. 1.

Posledná zmienka o hrade pochádza z roku 1457 a týka sa Ladislava Hunyadyho, ktorý ako trenčiansky župan nariadil kastelánom hradov v Trenčíne, Ilave a Žiline, aby nerušili Žilinčanov v ich výsadách, ktorými sú oslobodení od platenia mýta (Marsina 1975, 37).

Žigmund Luxemburský pokračuje v udel'ovaní privilégií a výhod mestu. V roku 1405 nariad'uje vybudovat' „obvykléc" hradby okolo mesta (Marsina 2008, 57). V roku 1414 rozkaz vydáva opakovane, pretože sa zdá, že mestská rada nevykazovala v danom smere žiadnu aktivitu. Hradby nestáli ani v septembri roku 1431, ked' mesto vyrabovali a vypálili táboritské vojská, vracajúce sa do Čiech (Prikryl-Štanský 1996, 4).

Problémy s fortifikáciou sa preniesli aj k d’alšiemu uhorskému panovníkovi, Matejovi Korvínovi, ktorý v roku 1474 „oslobodil Žilinu od platenia všetkých mimoriadnych daní po dobu troch rokov, pretože meštania mali vel’ké výdavky a námahu s budovaním opevnenia“ (Marsina 1975, 53).

Ked' mesto v roku 1540 dobyli bratia Ján a Rafael Podmanickí, prebudovali farský Kostol Najsvätejšej Trojice na pevnost' a dokončili výstavbu vedl'a stojacej Burianovej veže, ktorú upravili, aby slúžila nielen ako zvonica, ale aj ako obranná veža (Prikryl-Štanský 1996, 5-6). $\mathrm{Z}$ toho by sa dalo usudzovat', že hrad už nestál (poprípade už nedokázal plnit' svoju funkciu), 


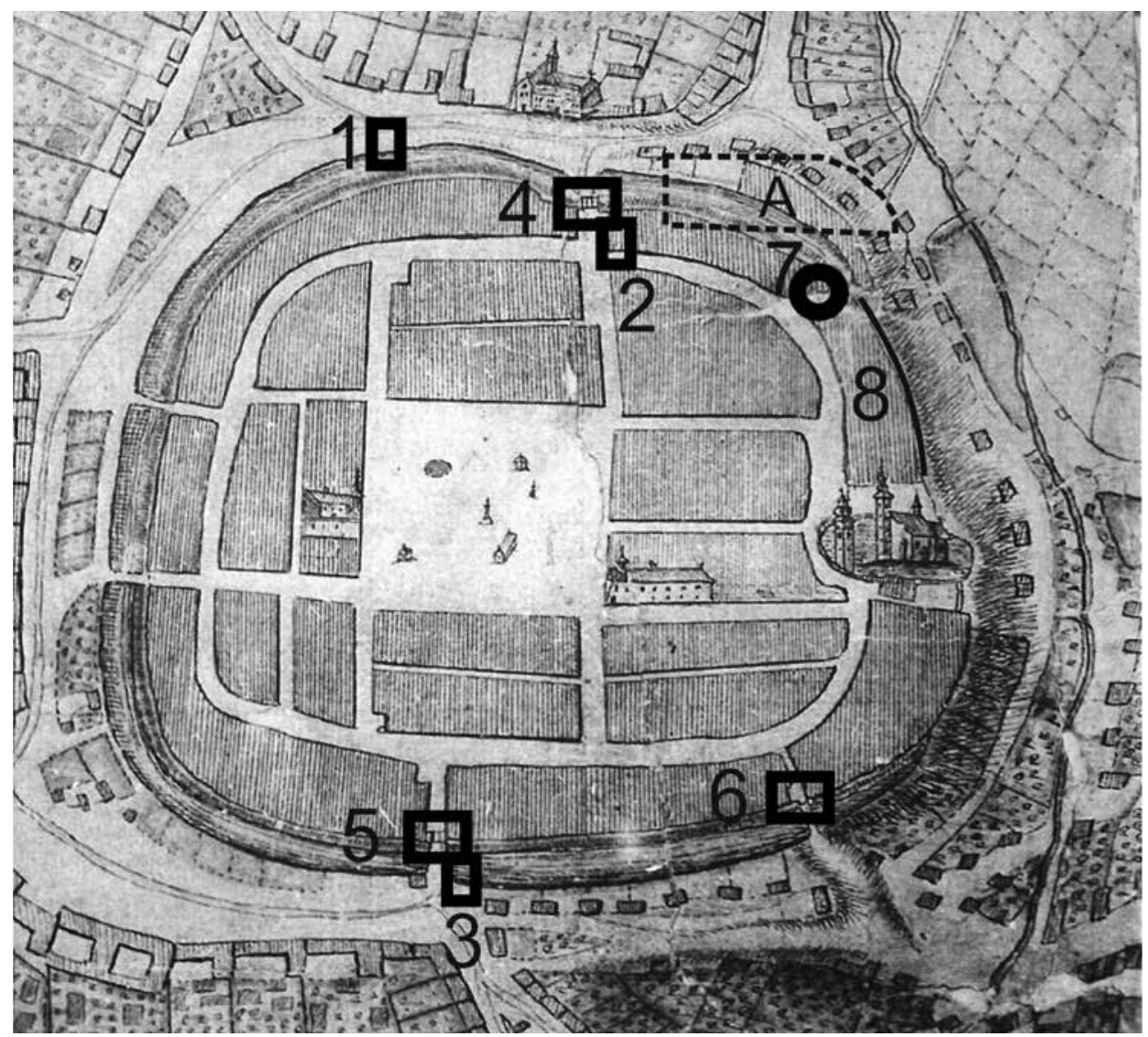

Obr. 2. „Zvláštny nárys polí mesta Žiliny“ z roku 1747 od Michala Ruttkaya-Nedeckého s vyznačením plochy výskumu (výrez). 1-3 - výskumy J. Moravč́́ka so zachytenými čast’ami mestského opevnenia: 1 - medzi ulicami Na priekope a Dolný Val (1974); 2 - Hodžova ulica (1995); 3 - križovatka ulíc Na bráne a Horný Val (1974); 4-5 - písomne doložené brány; 6 - bránka pre peších v ulici Čepiel; 7 - valcovitá veža hradu; 8 - ulica Štôlňa; A - plocha výskumu - Ulica J. M. Hurbana.

Abb. 2. „Sonderansicht der Felder der Stadt Žilina“ aus dem Jahr 1747 von Michal Ruttkay-Nedecký mit eingezeichneten Grabungsflächen (Ausschnitt). 1-3 - Grabungen von J. Moravčík mit den entdeckten Teilen der Stadtbefestigung: 1 - zwischen den Straßen Na priekope und Dolný Val (1974); 2 - Hodžova-Str. (1995); 3 - Kreuzung der Straßen Na bráne und Horný Val (1974); 4-5 - schriftlich belegte Tore; 6 - Fußgängertor in der Čepiel-Str.; 7 - zylinderförmiger Turm der Burg; 8 - Štôlňa-Str.; A - Grabungsfläche in der Straße J. M. Hurbana.

ked’že Podmanickí pristúpili k spomínaným stavebným úpravám. Čast’ tejto stavby bola zachytená J. Moravčíkom pri farskom kostole (Moravčík 2009, 20).

V roku 1620 sa objavuje prvá písomná zmienka o fortifikácii, kedy sa mesto ubránilo útoku asi dvoch tisícok ukrajinských kozákov (Prikryl-Štanský 1996, 6). Typ opevnenia však nie je udaný. Pravdepodobne z doby povstania Františka II. Rákociho, vymedzeného rokmi 1703-1711, pochádza druhý odkaz, ktorý už vyslovene uvádza ,zemné valy, drevené palisády a vodné priekopy“ (Prikryl-Štanský 1996, 9). Následne sa spomína i cisársky generál Ladislav Ebergényi, na rozkaz ktorého sa v roku 1708, tesne po vít'aznej bitke pri Trenčíne, okolo mesta vybudovali nové zemné valy (Prikryl-Štanský 1996, 9). Tento historický fakt je podporovaný i vhodnými urbanonymami, ktorými sú názvy ulíc Horný a Dolný Val, prípadne ulica Na priekope.

Na možnost' čiastočnej murovanej fortifikácie poukazuje zmienka z roku 1848, ked' dal meštanosta Ján Bittšánsky zvalit’ obe mestské brány, lebo prekážali pri odvážaní stavebnej deštrukcie po vel'kom požiari (Prikryl-Štanský 1996, 11). Jedna z brán pravdepodobne stála v ulici 
Na bráne, ktorá kolmo križuje ulicu Horný Val. Druhú murovanú bránu možno predpokladat' na opačnej strane mesta v identickej stavebnej situácii na priesečníku Hodžovej ulice a Dolného Valu. Tretia, písomne doložená bránka situovaná v dnešnej ulici Čepiel, bola určená len pre peších (Marsina 2010, 580).

Najstaršie mapové zobrazenie mesta i s blízkym okolím, tzv. „Zvláštny nárys polí mesta Žiliny“ z roku 1747 od Michala Ruttkaya-Nedeckého (obr. 2) zobrazuje všetky tri spomenuté priechody. Dva väčšie, ktoré by mohli zodpovedat' Bittšánskym strhnutým bránam a jeden menší, ktorým je určite bránka v dnešnej ulici Čepiel. Okrem nich sú na pláne ešte dva čepielskej bránke podobné priechody v juhozápadnej časti mesta (l'avá strana nákresu), ktoré by sa mohli situovat' na priesečník ulice Na priekope s ulicami Jána Vuruma a Jána Kalinčiaka. Okolo celého mesta je jasne rozpoznatel'ná vodná priekopa zmienená počas Rákociho povstania a pravdepodobne Ebergényim zbudované valy.

Archeologicky boli doteraz zachytené časti priekopy práve v blízkosti niektorých vyššie uvedených priesečníkov ulíc. Prvý objekt bol zachytený pri výkope základov pre budovu Štátnej banky na ulici Na bráne č. 1. J. Moravčík tu v roku 1974 zachytil na severovýchodnom profile priekopu s híbkou ca 2 metre od úrovne dlažby. Objekt so sivozelenou bahnitou výplňou datoval do časového obdobia 15. až prelomu 17. a 18. storočia. Odpadová vrstva v hornej časti priekopy dokladá stratu primárnej fortifikačnej úlohy a následné zavážanie odpadkami (Moravčík 1975, 66). Aj plocha medzi ulicami Na priekope a Dolný Val ponúka vel'mi podobný obraz, tu však J. Moravčík predpokladá zánik počas 16.-17. storočia, kedy bol objekt zavážaný odpadom, nakol'ko stratil svoj zmysel (Moravčík 1980, 40). Taktiež d’alšie dva Moravčíkove výskumy zachytili podobný obraz na Hodžovej ulici, čo je pár desiatok metrov západne od sledovaného výskumu na Ulici J. M. Hurbana. Tu je však vznik priekopy datovaný rámcovo do 14. storočia (Moravčík b. d.).

\section{Popis lokality a metódy výskumu}

Lokalita, na ktorej prebiehal výskum, sa nachádza v severozápadnej časti historického centra mesta (obr. 3). Skúmaná plocha mala tvar nepravidelného lichobežníka (a $=100 \mathrm{~m}, \mathrm{~b}=35 \mathrm{~m}$, $\mathrm{c}=75, \mathrm{~d}=45 \mathrm{~m}, \mathrm{va}=\mathrm{b}=35 \mathrm{~m})$ a zaberá parcely č. 166/1, 3, 4, 5, 6, 172/2, 186, 5747, 5749/1, 3, 5750 (obr. 4). Daný tvar je podmienený priestorom, ktorý bol bezprostredne po výskume zastavaný. Podl'a predbežných odhadov, ktoré boli podložené vyššie uvedenými historickými faktami i vhodnými urbanonymami v okolí lokality, sa dala na mieste predpokladat' archeologicky pozitívna situácia.

Dve novoveké priekopy boli zachytené v sondách S2, S3, stredoveká len v sonde S3. V sonde S2 boli celkom identifikované štyri výkopy, dvanást' výplní, trinást' vrstiev a tri historické konštrukcie. V sonde S3 boli celkom identifikované štyri výkopy, pätnást' výplní, osem vrstiev a dve historické konštrukcie. V súlade s harmonogramom stavebných prác a so získanými poznatkami o zničení častí terénu mladšou zástavbou z obdobia 18. až 19. storočia a recentnou masívnou úpravou pri jej asanácii bolo na ploche stavby realizovaných a dokumentovaných celkom devät' sond (R4 až R12, pričom S1 až S3 boli premenované na R1 až R3). Okrem toho boli sledované d'alšie zemné a stavebné terénne zásahy stavby, tieto však nepriniesli žiadne doklady archeologických situácií (Hoššo-Kováčik 2006).

Na väčšine plochy bola stredoveká priekopa zahĺbená do podložia predstavovaného svetlým žltohnedým piesčitým ílom. Nadložné vrstvy predchádzajúce vyhíbeniu priekopy neboli zachytené. Śírka tejto priekopy bola na reze R8-západ najmenej $5,5 \mathrm{~m}$ a híbka najmenej $1,25 \mathrm{~m}$, priekopa však bola $\mathrm{v}$ týchto miestach evidentne $\mathrm{z}$ oboch strán narušená barokovou priekopou a mladšou zástavbou (obr. 5). Na rezoch R3-východ a R3-západ bola šírka stredovekej priekopy už najmenej $7 \mathrm{~m}$, dochovaná híbka bola však len $1 \mathrm{~m}$ (obr. 6,7). Rez R11 bol s ohl'adom na celistvost' nálezovej situácie stredovekej priekopy najzachovalejší, celková šírka priekopy bola minimálne $8 \mathrm{~m}$, šírka dna bola $5 \mathrm{~m}$ a híbka bola najmenej 1,5 m (obr. 8a, b; Kováčik-Moravčík-Schön 2008, 89). Definitívny zánik stredovekej priekopy predpokladajú autori výskumu v priebehu 


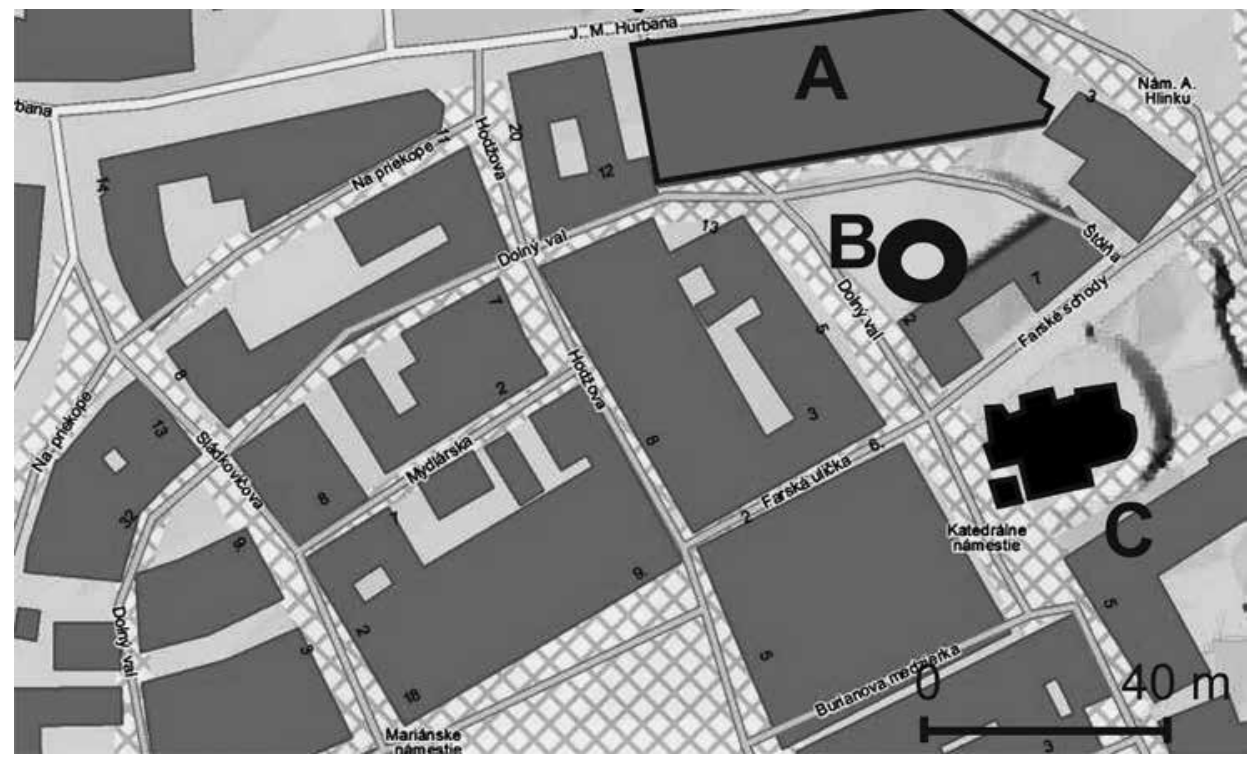

Obr. 3. Žilina, historické centrum. Poloha lokality - výskum na Ulici J. M. Hurbana v roku 2008. A - plocha výskumu, B - valcovitá veža hradu, C - farský Kostol Najsvätejšej Trojice. Zdroj www.mapy.sk.

Abb. 3. Žilina, historisches Zentrum. Lage der Fundstelle - Grabung in der Straße J. M. Hurbana im Jahr 2008. A - Grabungsfläche, B - zylinderförmiger Turm der Burg, C - Dreifaltigkeitskirche. Quelle www.mapy.sk.

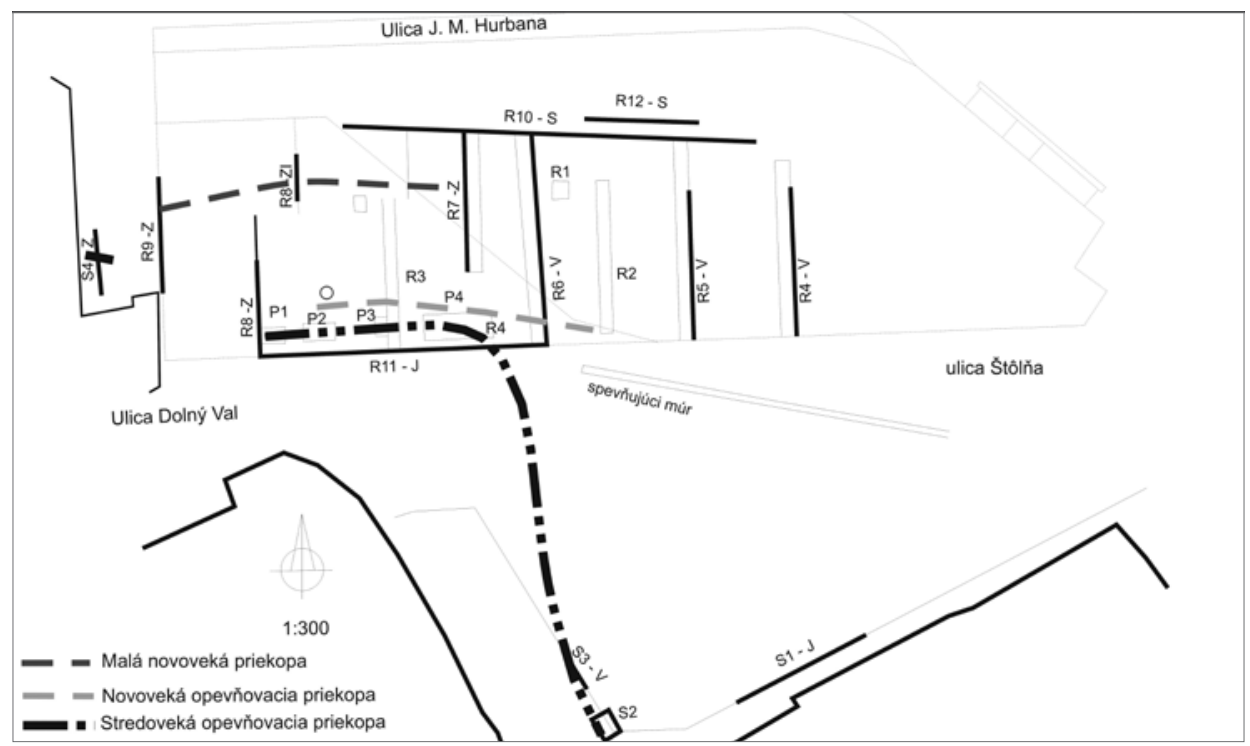

Obr. 4. Žilina, historické centrum. Plán lokality - výskum na Ulici J. M. Hurbana v rokoch 2005 až 2006. Podl’a Hoššo-Kováčik 2006. Abb. 4. Žilina, historisches Zentrum. Planskizze der Fundstelle - Grabung in der Straße J. M. Hurbana in den Jahren 2005 und 2006. Nach Hoššo-Kováčik 2006.

16. či 17. storočia, počas masívnej vyrovnávky terénu pred vybudovaním novej fortifikačnej priekopy. Zaniknutú stredovekú priekopu totiž porušoval mladší priekopovitý útvar 502, resp. 526 (obr. 4, 5, 6). Dno výkopu znovu pokrývala kašovitá vrstva 110, ktorá azda pochádza z doby funkcie výkopu. Zdá sa, že výskum zachytil nielen hlavný prstenec novovekej priekopy, ale 
pravdepodobne ešte aj menší paralelne predsunutý priekopovitý útvar z toho istého obdobia. Šírka hlavnej novovekej priekopy bola na reze R3-východ minimálne 4,2 $\mathrm{m}$ a hĺbka približne $1,1 \mathrm{~m}$ (Hoššo-Kováčik 2006, 58). Novoveké priekopy sú podl'a autorov výskumu híbené následne po zasypaní stredovekej. Barokové priekopy na rozdiel od svojej staršej predchodkyne viedli od severovýchodného ohybu stredovekej priekopy d’alej na východ, jej pokračovanie vel'mi pravdepodobne indikuje priebeh ulice Štôlňa (obr. 2, 4; Kováčik-Moravčík-Schön 2008, 90).

\section{Nálezový súbor}

Nálezový súbor pochádza z lokality, na ktorej prebiehala od vzniku vrcholnostredovekého mesta čulá stavebná i deštrukčná činnost'. Poloha bola naviac od tohto obdobia nepretržite osídlená. Táto intenzívna l’udská aktivita sa zrkadlí v kvalite zachovania nálezov. Vcelku sa nedochoval žiaden artefakt a ani s pomocou rekonštrukcií sa nepodarilo uviest' čo i len jeden

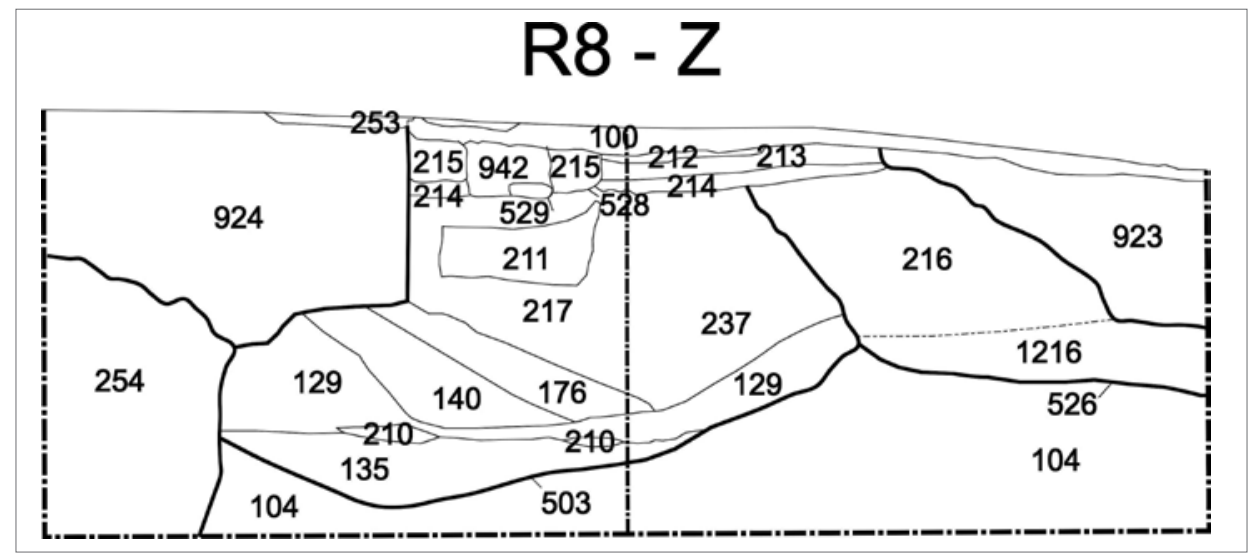

Obr. 5. Žilina, historické centrum. Rez R8-západ - výskum na Ulici J. M. Hurbana v rokoch 2005 až 2006 (1:50). Podl’a HoššoKováčik 2006.

Abb. 5. Žilina, historisches Zentrum. Schnitt R8-Westen - Grabung in der Straße J. M. Hurbana in den Jahren 2005 und 2006 (1:50). Nach Hoššo-Kováčik 2006.

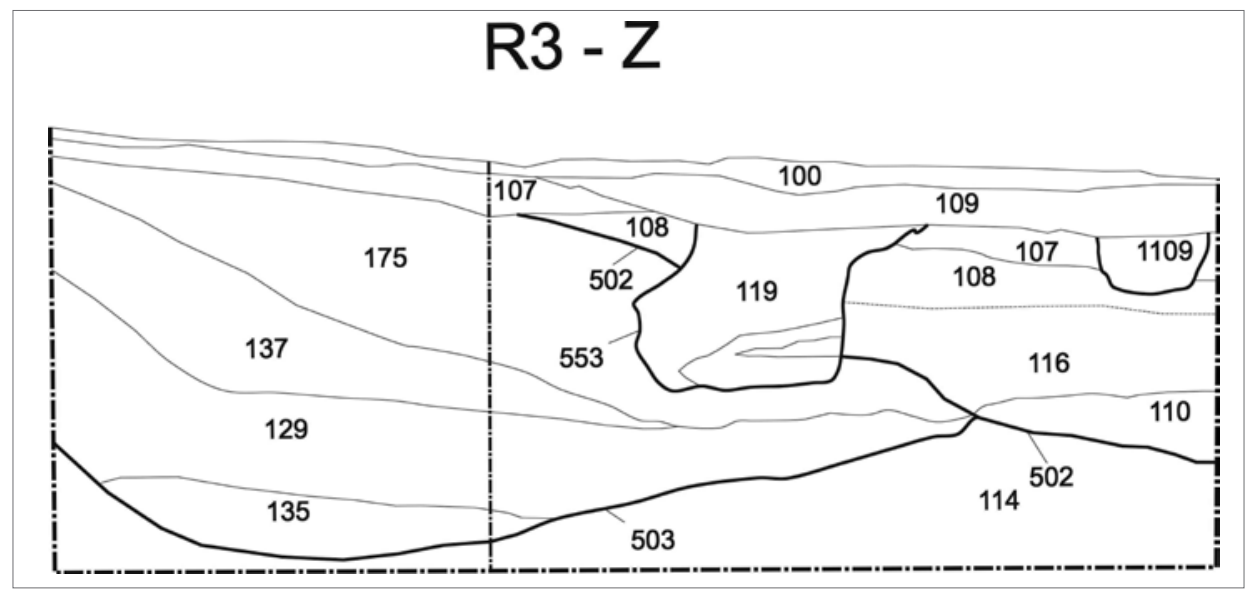

Obr. 6. Žilina, historické centrum. Rez R3-západ - výskum na Ulici J. M. Hurbana v rokoch 2005 až 2006 (1:50). Podl’a Hoššo-Kováčik 2006.

Abb. 6. Žilina, historisches Zentrum. Schnitt R3-Westen - Grabung in der Straße J. M. Hurbana in den Jahren 2005 und 2006 (1:50). Nach Hoššo-Kováčik 2006. 
exemplár do úplného, pôvodného stavu. Pravdepodobne ide najmä o výrobky, ktoré boli poškodením vyradené z kolobehu bežného života. Výnimkou je snád' sekundárne upravená čast' vydutiny, ktorá by mohla plnit' úlohu tzv. hrnčiarskej čepele. Okrem toho je možné, práve vd’aka vysokej urbanizačnej aktivite, premiešanie jednotlivých vrstiev, čomu by napovedal napr. nález úlomku porcelánovej nádoby v ranonovovekej vrstve. Samozrejme, možnost' existencie porcelánového riadu v meste $\mathrm{v}$ tomto období úplne vylúčit' nemôžeme, ale podl'a doterajších poznatkov je vysoko nepravdepodobná (Hoššo 2004, 576-577).

Pre nálezový súbor získaný z obranných priekop je typická značná torzovitost', ktorá st’ažuje vytvorenie typologického rozboru. Medzi fragmentmi jasne dominujú zväčša neurčitel'né fragmenty z vydutín vyšších hrncovitých nádob a archeologicky citlivé časti, ktoré sú pre danú keramiku podstatné, sú v pomernej menšine.

Ako vo väčšine stredovekých miest i tu prevládajú hrnce (pravdepodobne prevažne s uchom) a jednoduché džbány hrncovitého tvaru. Ďalšími početne zastúpenými predstavitel'mi vrcholno- a neskorostredovekého obdobia v nálezovom celku sú misy-pernice a rôzne typy gotických pohárov, často v hrubšom prevedení, aké je charakteristické pre tzv. bratislavské poháre. K stredovekým nálezom sa radia i pokrievky zvoncovitého charakteru. Posledným, ešte stredovekým typom sú trojnožky.

V mladších vrstvách staršej priekopy, rovnako ako v samotnej novovekej priekope, je stále väčšinovým tvarom hrniec (avšak už výrazne účelovo členený). Sekundujú mu najmä nové, široko roztvorené miskovité a tanierovité tvary. Nárast počtu plochejších nádob je charakteristickým znakom tohto obdobia (Hoššo 1988, 121). Objavilo sa aj niekol'ko plochých tanierov, ktoré sa pravdepodobne vyvinuli z drevených predchodcov (Ruttkay 1995, 580). Prvýkrát sa v žilinskom súbore objavujú kachlice, avšak výlučne komorového typu.

Po materiálovej stránke prevládajú v sledovanom súbore počas celého skúmaného obdobia jednoduché, oxidačne vypálené keramické triedy 1, 2 a 3 (zastúpenie v súbore 12,63\%, 10,98\% a 28,55 \%; Španihel 2014, 143). Vždy ide o keramiku oranžovej, hnedej až okrovej farby s občasným zafarbením dosiva. Ako ostrivo prevažuje piesok a muskovit, výnimočne štrk a prach. Materiálovo sa tieto triedy radia od jemnej po hrubú. Vždy sú vypalované oxidačne, technologická úroveň prežahu je nekvalitná až kvalitná. Pri najmenej kvalitných kusoch sa na lome objavuje sendvičový efekt. Farba lomu sa zhoduje s farbou materiálu na povrchu črepu. Z tejto keramickej masy boli produkované najmä hrnce, jednoduchšie džbány, misy-pernice, ploché taniere a kachlice.

$\mathrm{Z}$ tried, ktoré sú redukčného pôvodu, dominuje keramika šedej až tmavošedej farby s lomom rovnakej farby keramickej triedy 10 (10,80\%). Používaným ostrivom je piesok a muskovit. Ide o stredne hrubý materiál so stredne kvalitným až kvalitným výpalom. Z tohto materiálu boli vyrábané hlavne tzv. gotické poháre. Sekunduje jej vel'mi kvalitná šedá keramika triedy 11 (7,14 \%; Španihel 2014, 143) s výrazným kovovým leskom, na poklep zvoní, s jemnou štruktúrou a prachovým, či jemným muskovitovým ostrivom (Španihel 2014, 1435).

Metóda oxidačného výpalu výrazne prevažovala $(70,34 \%)$ nad redukčným výpalom (29,66\%). Výpal s prístupom kyslíka, regiónu vlastný, vychádza z miestnych tradícií. Redukčný výpal sa výraznejšie uplatňuje len v Žiline (Hoššo 1983, 221), a aj to len počas vrcholného stredoveku. V ranom novoveku sa tento typ výpalu neobjavuje už ani v Žiline (Španihel 2014, 155).

V nálezovom celku dominuje neglazovaná keramika (79,78\%). Glazovaná či ináč šlachtená keramika bola omnoho menej početná $(20,22 \%)$. Glazúra očividne ešte nemá výzdobnú funkciu, pretože nádoby sú polievané len zvnútra, často iba tesne okolo okraja, prípadne s malým presahom.

Výnimku tvoria tanierovité tvary, ktoré sú výrazne zdobené rôznymi postupmi. Od jednoduchého jednofarebného náteru hlinkou cez mal'bu hlinkami, samostatne i v kombinácii s glazúrou, sgrafita s glazúrou, farebných kombinácií glazúr až po kombináciu glazúry s rytým dekórom (Španihel 2014, 150).

Najstaršie artefakty reprezentuje súbor zo stratigrafickej jednotky 135 (obr. 5, 6, 7). Daná vrstva pravdepodobne predstavuje nedostatočne vyberaný odpad hromadiaci sa na dne funkčnej 
stredovekej priekopy, čomu zodpovedá spôsob ul'ahnutia vrstvy v podobe rovnomerného ukladania sedimentu. Najreprezentatívnejšou nádobou je rekonštruované torzo oxidačne vypáleného súdkovitého hrnca s rímsovitým okrajom hnedej farby (tab. 1:1). Nádoba je zdobená zväzkom rýh na hrdle, nepravidelnou hrubou rytou vlnovkou na pleci a ryhami rovnakého prevedenia na tele. Výrazné stopy po podsýpke na dne poukazujú na pomaly rotujúci ručný kruh. Analogický hrniec datovatel'ný do prvej polovice 14. storočia pochádza z Radole-Kosceliska (Španihel 2014, 166, tab. XVI:2).

Prevažná väčšina črepov má obdobný charakter. Pokial' je to rozpoznatel'né, nádoby inklinujú k súdkovitému telu, opakovane sa vyskytuje hrubo prevedená vlnovka v rôznych variantoch a výrazné nepravidelné ryhy, či už samostatne, alebo vo vzájomnej kombinácii s vlnovkou. Doložené okraje patria medzi rímsovité typy (tab. 1:2). Dná sú zásadne podsýpané pieskom.

Odlišnú skupinu nálezov reprezentujú hrubé redukčne vypálené fragmenty pohára (tab. 1:3) a zvoncovitej pokrievky (tab. 1:4). Pohár bez okrajovej časti má masívne telo valcovitého charakteru len s náznakmi členenia. I tu sa vo výzdobe uplatňujú hrubé nepravidelné ryhy. Jemnejšia verzia nádoby zachovávajúca líniu spodnej časti pochádza zo Štúrovej ulice v rovnakom meste (Bielich-Vangl’ová-Zajacová 2012, 210, obr. 7:8), kde je datovaná rámcovo do 14.-15. storočia.

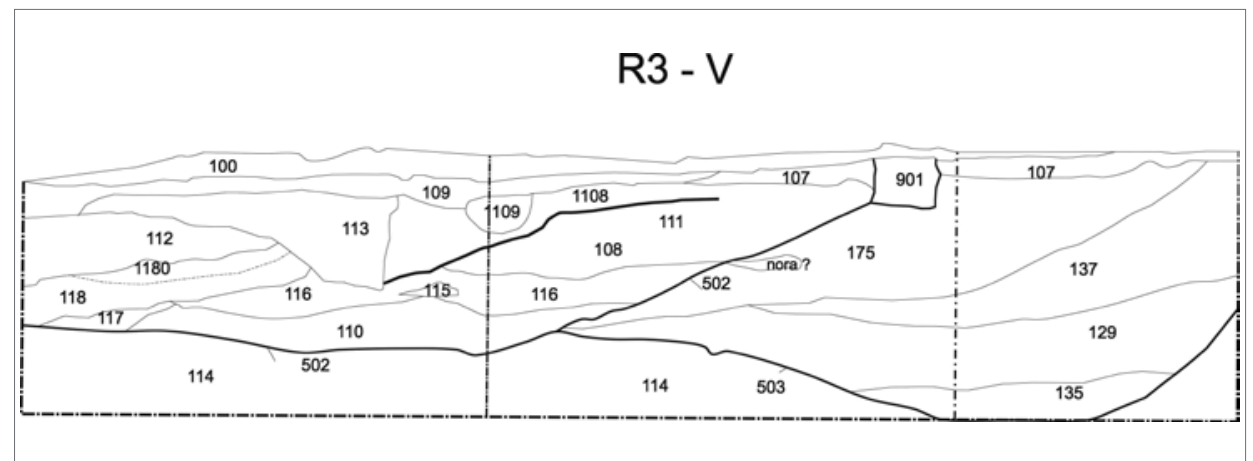

Obr. 7. Žilina, historické centrum. Rez R3-východ - výskum na Ulici J. M. Hurbana v rokoch 2005 až 2006 (1:50). Podl’a HoššoKováčik 2006.

Abb. 7. Žilina, historisches Zentrum. Schnitt R3-Osten - Grabung in der Straße J. M. Hurbana in den Jahren 2005 und 2006 (1:50). Nach Hoššo-Kováčik 2006.

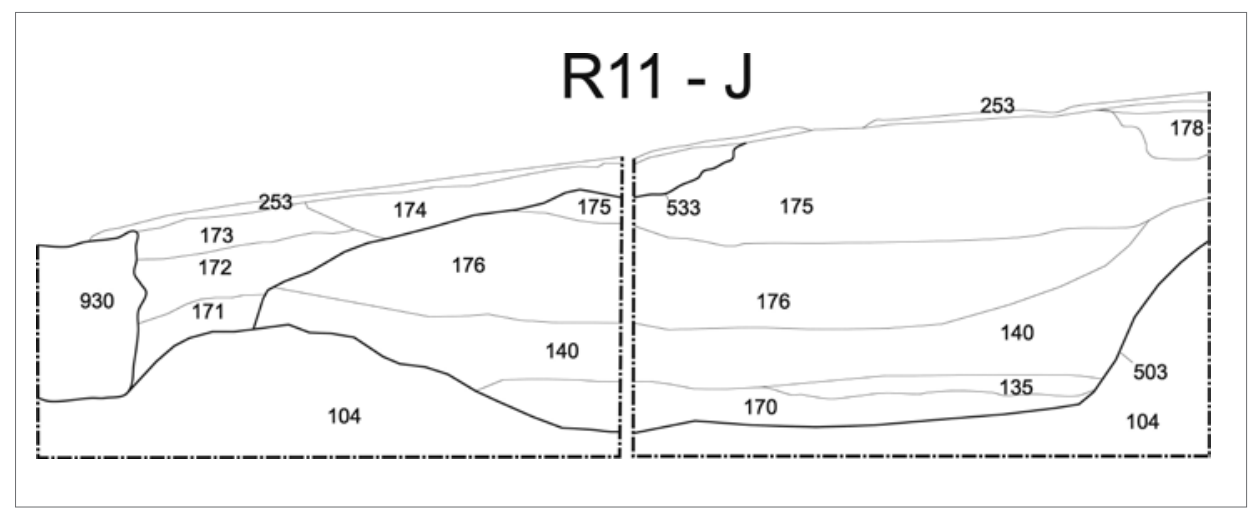

Obr. 8. Žilina, historické centrum. Rez R11-juh - výskum na Ulici J. M. Hurbana v rokoch 2005 až 2006 (1:20). Podl’a Hoššo-Kováčik 2006.

Abb. 8. Žilina, historisches Zentrum. Schnitt R11-Süden - Grabung in der Straße J. M. Hurbana in den Jahren 2005 und 2006 (1:20). Nach Hoššo-Kováčik 2006. 


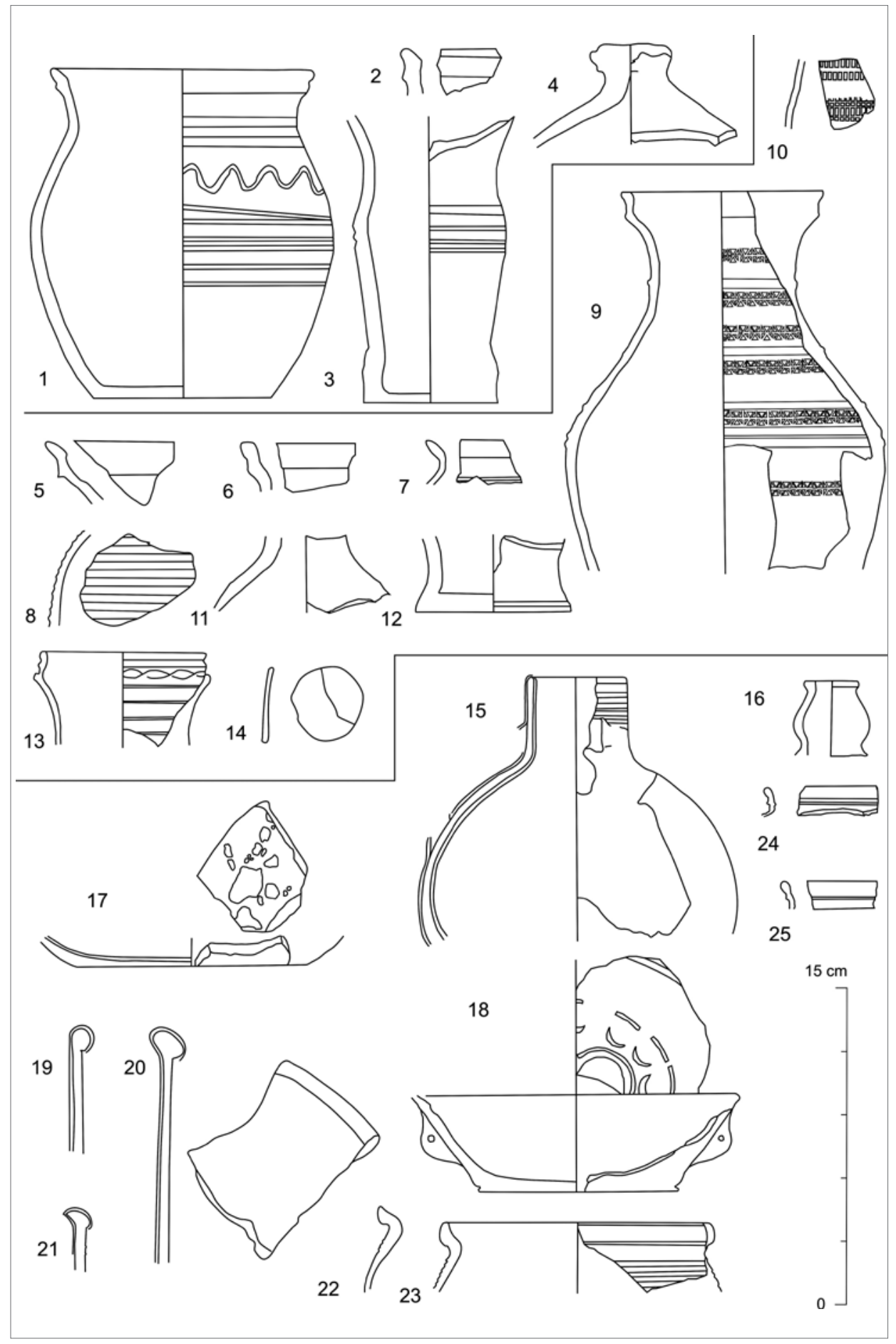

Tab. 1. Žilina, Ulica J. M. Hurbana. Výber keramiky z obranných priekop. Kresba S. Španihel.

Taf. 1. Žilina, Straße J. M. Hurbana. Keramikauswahl aus den Verteidigungsgräben. Zeichnung S. Španihel. 
Vel'ký fragment pokrievky s nepravidelným kužel'ovitým telom a hrubým gombíkom nie je vhodnou oporou pre datovanie, nakol'ko pokrievky nie sú vel'mi chronologicky citlivé. Samozrejme, vyslovene hrubé prevedenie a absencia esovito profilovanej steny hovorí pre starší pôvod. Zaujímavý je skôr jej redukčný výpal so zretel'om na to, že všetky hrnce vo vrstve sú oxidačného pôvodu. To korešponduje so zistením z ned’alekého hradu Lietava, kde boli hrnce vyrábané zásadne oxidačnou cestou, no drvivá väčšina pokrievok prežahom bez prístupu vzduchu (Španihel 2014a, 97).

Stratigrafická jednotka 129 (obr. 5, 6, 7) je očividne najstaršou skutočne zásypovou vrstvou stredovekej priekopy, čo dokladá zachytená poloha a sklon uloženiny. Materiálové zloženie približne zodpovedá predchádzajúcemu horizontu i pomerovo, s výnimkou mierne zvýšeného zastúpenia redukčne vypalovaných tried.

Typologicky, samozrejme, prevláda hrniec, podla fragmentov tiež súdkovitého tvaru, avšak už s jednoduchým vyhnutým okružím (tab. 1:5, 6), vzácne doplnený uchom. Výnimočne sa objaví už i zjednodušený vyhnutý okraj (tab. 1:7). Okružia sú reprezentované kratším a len málo vyhnutým okrajom, ktorý je bežný pre oblast's farebnou keramikou. Podobné pochádzajú z blízkeho okolia, napríklad zo žilinskej Štúrovej ulice (Bielich-Vanglová-Zajacová 2012, 209, obr. 6:9), jaskyne pod hradom Hričov (Španihel 2014, 166, tab. II:11) či z gbelianskeho väčšieho hradiska (Moravčík 1977, 188). Na dnách sú prevažne doložené známky podsýpky, objavujú sa i prvé strunou snímané kusy.

Ostatné tvary reprezentuje pohár, misa, džbán či zvoncovitá pokrievka. Z výzdoby sa stráca vlnovka, naopak rôzne typy ryhovania a žliabkovania sú prevedené kvalitnejšie (tab. 1:8). Rozstupy a vel'kost' jednotlivých zväzkov rýh sa stávajú pravidelnejšími a výsledný obraz ponúka jednotný vizuálny dojem.

Prvýkrát je doložený kvalitne redukčne vypálený kovovolesklý džbán, ktorého predlohu nachádzame v Pol'sku, a to vo Wrocłave (Limisiewicz a kol. 2002, 94, ryc. 86:f). Kvalitný materiál, tvar i na regionálne pomery zložitá kolieskom vyhotovená dekorácia figurujúca len na dvoch identických (tab. 1:9) džbánoch a jednom hrnci predpokladá možnost' importu zo severu.

Jednoduchšia geometrická forma dekorácie tohto typu sa v danej vrstve objavuje často, avšak vždy len na redukčnej keramike (tab. 1:10). Výzdoba kolieskom sa bežne viaže práve na keramiku vypal'ovanú bez prístupu vzduchu a jej najrozšírenejšie využívanie spadá do druhej polovice 15. storočia (Hoššo 1983, 219). Pre vhodné analógie netreba chodit' d'aleko, pochádzajú zo starších výskumov v samotnej Žiline (Moravčík 1970, 20-22) či blízkych Visolajoch - Jankovom Háji, prípadne na hrade Košeca (Španihel 2014, 166, tab. II:5, 6, 9, 10).

$\mathrm{K}$ bežnej redukčnej keramike radíme i niekol'ko fragmentov zvoncovitých pokrievok, u ktorých sa už v náznakoch začína objavovat' esovitá profilácia (tab. 1:11). Rovnako fragmenty dien pohárov sú už prevedené jemnejšie, objavuje sa i nevýrazná nožička (tab. 1:12). Doložený okraj s vysokým zatiahnutým okružím je dokonca dekorovaný prepletanou plastickou lištou (tab. 1:13). Takto zdobený okraj pochádza napríklad z blízkej Lietavy (Španihel 2014, 171 tab. V:7) či priamo z mesta (Šedo 1875a, obr. 88:9), no známe sú i vzdialenejšie analógie, napríklad z Kežmarku (Polla 1971, 39, obr. 46:2). Dná pohárov svojou profiláciou s náznakom nožičky tiež zodpovedajú vyššie uvedeným nálezom. Obdobné tvary sú doložené i priamo v meste, opät' zo Štúrovej ulice, kde sú datované na koniec 14. až začiatok 15. storočia (Bielich-Vangl'ová-Zajacová 2012, 210, obr. 7:4, 5). Podobné fragmenty, no oxidačne vypal'ované, sa našli i v Banskej Bystrici v Benického dome (Mácelová 1986, 485, obr. 5:2, 3, 6), kde sú rámcovo datované do 15. storočia a stavebným prieskumom zaradené presnejšie do jeho začiatku.

Zriedkavost'ou je okrúhly fragment vydutiny, pravdepodobne hrnca z jemnejšej hliny, slúžiaci azda ako hrnčiarska čepel' (tab. 1:14). Prakticky identický predmet, no bez popisu, pochádza zo studne na Hviezdoslavovej ulici v Trnave (Barteková 2012, 138, obr. 7:8).

Stratigrafická jednotka 140 (obr. 5) je druhou, mladšou vrstvou dosadajúcou na vrstvu 135 a je obsahovo najbohatším súborom celého nálezového celku. Obsahuje prevažne hrnce, pokrievky a trojnožky. Prvýkrát sa objavujú široko roztvorené tanierovité tvary. Naopak, hlinené poháre už absentujú. Ako nový prvok sa vyskytli komorové kachlice (táto vrstva ich obsahovala 
najviac) a drobné úlomkovité tyčinky zo skla. Je teda možné pripustit' i výskyt sklenených pohárov (Pajer 1983, 50).

Okrem jednoduchých vyšších hrncovitých nádob boli nájdené aj fragmenty džbánu s gulovitým telom, na ktoré bolo nasadené valcovité hrdlo zakončené cylindrickým okrajom (tab. 1:15). Nádoba je potrená kvalitnou tmavohnedou glazúrou z vonkajšej strany a transparentnou z vnútornej strany. Obdobné krčahy sú známe najmä z Dolného Sliezska (Szwed 2004, 373, tab. 8:11, 17). Konsolidáciou názorov R. Szweda $(2004,37)$ a J. Hošša $(1988,116-118)$ by sme datovali žilinský exemplár do záveru druhej polovice 16. alebo až na prelom 16. a 17. storočia.

Ojedinelým nálezom je pravdepodobne horná čast' džbánu s úzkym fl'aškovitým ústím z vel'mi jemnej hliny (tab. 1:16). Tento typ džbánu nie je pre produkciu severozápadného Slovenska vôbec bežný. Omnoho častejšie sa nachádza na južnom Slovensku (Březinová-Samuel 2007, 67, obr. 84:i) už od konca stredoveku.

Klasická líniová rytá výzdoba keramiky sa zahust’uje a obmedzuje svoj výskyt na jednu až pät’ rýh, výnimočne žliabkov, umiestnených prevažne na podhrdlie či plece nádoby.

Do popredia vystupuje olovená glazúra, i ked' zatial' len ako technický prvok, nakol'ko bola aplikovaná len na vnútornej strane a okraji. Plošne bifaciálne, a teda už aj s dekoračným úmyslom, je glazovaný iba vyššie spomínaný gul'ovitý džbán.

Použitie glazúry je najvýraznejšie badatel’né na tanieroch a miskách, kde sa uplatňujú dva výzdobné postupy. Prvou, staršou formou je zelenohnedá glazúra s čiernymi fl'akmi (tab. 1:17) alebo, ako ich označuje J. Hoššo, terčíkmi, pričom tento typ dekorácie datuje do druhej polovice 16. storočia $(1988,119)$. Mladšou verziou je kombinácia zelenej a hnedej glazúry na podklade z bielej hlinky, tvoriacej koncentrický mesiačikovitý motív (tab. 1:18). Obdobné výzdobné prvky poznáme napríklad z Bratislavy (Polla 1979, tab. XX:7).

Niekol'ko nájdených tanierovitých okrajov z Ulice J. M. Hurbana (tab. 1:19, 20, 21) má analógie napríklad z nitrianskej Mostnej ulice (Březinová-Samuel a kol. 2007, 66, obr. 83, 55, obr. 76), kde je keramický súbor datovaný rámcovo do 16.-18. storočia. Avšak široká škála vyslovene presných analógií pochádza z wrocławskej Ulice św. Antoniego (Szwed 2004, tab. 12:10, 11, 14:1, 2), kde sú datované presnejšie, na prelom 16.-17. storočia.

Okraje vyšších hrncovitých nádob sú najmä zjednodušené vyklonené varianty jedného typu (tab. 1:22, 23), pričom jeho analógie sú l’ahko dostupné v regióne, napríklad na hrade Lietava, kde sa dá nájst’ množstvo mierne pozmenených verzií (Španihel 2014a, 98, obr. 2:5). Príležitostne sa objaví minimalizované vyhnuté oblé okružie (tab. 1:24, 25), ktorého obmeny sú tiež bežnou záležitost’ou v oblasti, analógie sú aj priamo z mesta, napríklad z Mariánskeho námestia (Moravčík 1970, 20-22), ale aj zo Strečna (Šedo 1975b, obr. 86:5), či opät' z Lietavy (Španihel 2014a, 98, obr. 1:5). Všetky určitel’né dná už nesú známky zrezávania z kruhu.

Drvivá väčšina nálezov kachlíc z Ulice J. M. Hurbana pochádza práve z tejto stratigrafickej jednotky. Hoci sa ich výzdoba nesie v renesančnom duchu, čoho je najkrajším príkladom kachlica s motívom antropomorfnej Pýchy, ktorá je oblečená v bohatých dobových šatách, objavia sa i prvky neskorej gotiky.

Súboru rozmerovo dominuje fragment neglazovanej kachlice s prakticky kompletne zachovanou čelnou vyhrievacou stenou. Ide o obdížnikovú plochu s rozmermi $148 \times 264 \mathrm{~mm}$, s absentujúcou okrajovou lištou a vel'mi zle zachovanou stenou plášta. Výzdobný motív zobrazuje bud' priečelie krest’anského chrámu s vežičkami a polkruhovým objektom, ktorý pripomína gotické rozetové okno, alebo alegoricky zobrazený Boží hrob so svietnikmi (tab. 2:7). Architektonický objekt je vyobrazený čelne, čo je typické pre gotické zobrazovanie, na rozdiel od perspektívneho videnia stavby, uživaného v renesancii (Hoššo 2004, 575-576). Námet i jeho výtvarné vyhotovenie je vel'mi vzácne, nájst' teda vhodnú analógiu bolo značne problematické. Jedinú, i ked' vel'mi vzdialenú paralelu je možné badat' na prerezávanej kachlici, ktorá sa nachádza v budapeštianskom Historickom múzeu (Gebhard 1980, 69, Abb. 46).

Druhým zaujímavým nálezom z tejto vrstvy je už spomínaná kachlica s motívom sediacej ženy (tab. 2:8). Tiež je neglazovaná a vel'mi dobre zachovaná, podla analogických zobrazení pravdepodobne štvorcového tvaru, čelná vyhrievacia stena so zachovanou trojnásobne hrano- 
lovou okrajovou lištou, pričom najvyšší stupeň je jednostranne zaoblený. Ústredným motívom je teda sediaca žena v prepychových renesančných šatách, ktorá sa kochá svojím obrazom v zrkadle. Pri nohách jej stojí pravdepodobne páv. Celý výjav je vsadený do zdobeného kruhového medailónu. Ide o tzv. antikizujúci motív, konkrétne o personifikáciu pýchy. Tento vyslovene renesančný námet sa na území Slovenska začína objavovat' od druhej polovice 16. storočia, i ked' ich väčšie rozšírenie je badatel'né najmä na začiatku a v prvej polovici 17. storočia. Analogicky vhodné kachlice, avšak s vyššou výtvarnou a technologickou úrovňou, pochádzajú z Berlína a Mníchova (Strauss 1983, Taf. 65:1, 2). Obe sú datované na prelom 16. a 17. storočia. Inšpirácia nemeckým prostredím je zjavná. Hrnčiar sa inšpiroval i v takých detailoch, akým je poloha rúk či tvar zrkadielka. Tento motív je v regióne populárny, v meste sa vyskytol ešte na lokalite $\mathrm{Na}$ bráne 1 (Moravčík 1975, obr. 45:1). Doložený je i variant v podobe stojaceho obdĺžnika, dokonca zeleno glazovaný z hradu Strečno (Španihel 2014, 152). Zaujímavost'ou je, že kachle reprezentujúce l’udské vlastnosti, v tomto prípade jeden zo smrtel'ných hriechov (iné varianty predstavujú napríklad l'udské cnosti, slobodné umenia, starozákonných hrdinov a pod.), sa bežne vyskytujú v ustálených sériách, v ktorých sú rovnomerne zastúpené všetky personifikácie, no na Hornom Považí sa z „hriešnej série“ doteraz našla vždy len Pýcha.

Početnú skupinu kachlíc s renesančnými výzdobnými motívmi reprezentujú rôzne menšie úlomky s dekoráciou v podobe geometrických alebo geometricko-rastlinných prvkov.

Prvým z geometrických vzorov je neglazovaná kachlica z jemného materiálu, pravdepodobne štvorcového tvaru (tvar predpokladáme na základe nižšie uvedených analógií; tab. 2:9). Opät' ide o fragment čelnej vyhrievacej steny s dobre zachovanou dvojnásobne hranolovitou okrajovou lištou a častou komorového plášta. Celú plochu kachlice pokrýva diamantový vzor. Tento motív sa v drobnej obmene vyskytol ešte na jednej kachlici. Čelná vyhrievacia stena je roztrieštená na množstvo fragmentov, na ktorých sa výnimočne zachovala i okrajová lišta rovnakého typu ako u predchádzajúcej kachlice. Vhodné analógie poznáme zo Solné ulice v Opave (Krasnokutská 2005, 16-17), ale najmä z Brna, kde bol tento motív vo viacerých variantoch vel'mi oblúbený (Loskotová 2008, 142, obr. 509). Podl'a analógií spadá do druhej polovice 16. až na začiatok 17. storočia.

Iný úlomok kachlice je zdobený vzájomne sa prekrývajúcimi hrubými štylizovanými listami (tab. 2:10). Úlomok bol glazovaný, no poleva sa zachovala vo vel'mi zlom stave, pravdepodobne ide o klasickú olovenú glazúru.

Poslednou položkou medzi kachlicami v stratigrafickej jednotke 140 sú dva fragmenty zeleno glazovanej kachlice s komplikovanou okrajovou lištou a dobre zachovaným kužel'ovitým komorovým pláštom (tab. 2:11). Ústredným motívom je Ukrižovanie Krista, čo sa dá vyvodit' zo zachovanej časti ruky pribitej na kríži. Bohužial', postava Krista a jeho prípadných adorantov sa nezachovali. Celý výjav je ohraničený architektonicky nezaraditel'ným oblúkom. Motív Kristovej mučeníckej smrti sa medzi kachliarskymi výzdobnými motívmi objavuje už začiatkom druhej polovice 15. storočia (Hazlbauer 1998, 113-116) a udržiava sa i v ranom novoveku. Naviac je jedným z mála krest’anských motívov, ktoré sa vyskytovali v katolíckych i protestantských domácnostiach. Rozličnost' vierouky objasňovali práve postavy vedl'a Spasitel'a, ktoré na tejto kachlici chýbajú. V renesančnom období je známa široká škála sprievodných adorantov. Či už išlo o dvojicu anjelov a Pannu Máriu so sv. Jánom na katolíckych kachliach, alebo na protestantských výrobkoch zobrazované osobnosti náboženského života, ako napríklad Martin Luther v sprievode d’alšej významnej postavy reformácie, poprípade starozákonné dvojice, ako napríklad Mojžiš s medeným hadom a Abrahám obetujúci Izáka (Brych 2004, 24). Ked’že v Žiline boli hojne zastúpené obe krest’anské frakcie, bez vyššie uvedených sekundárnych znakov je nemožné otázku príslušnosti k tej, či onej frakcii vyriešit'. Čo sa týka chronologického zaradenia, vd’aka už spomínanému širokému časovému rozpätiu, v ktorom bol daný motív používaný, je samotné datovanie vel'mi všeobecné. Vzhl'adom na technologické parametre a ostatné kachlice z tejto vrstvy túto kachlicu i ostatné drobné úlomky radíme do druhej polovice 16. storočia až prvej štvrtiny 17. storočia. 


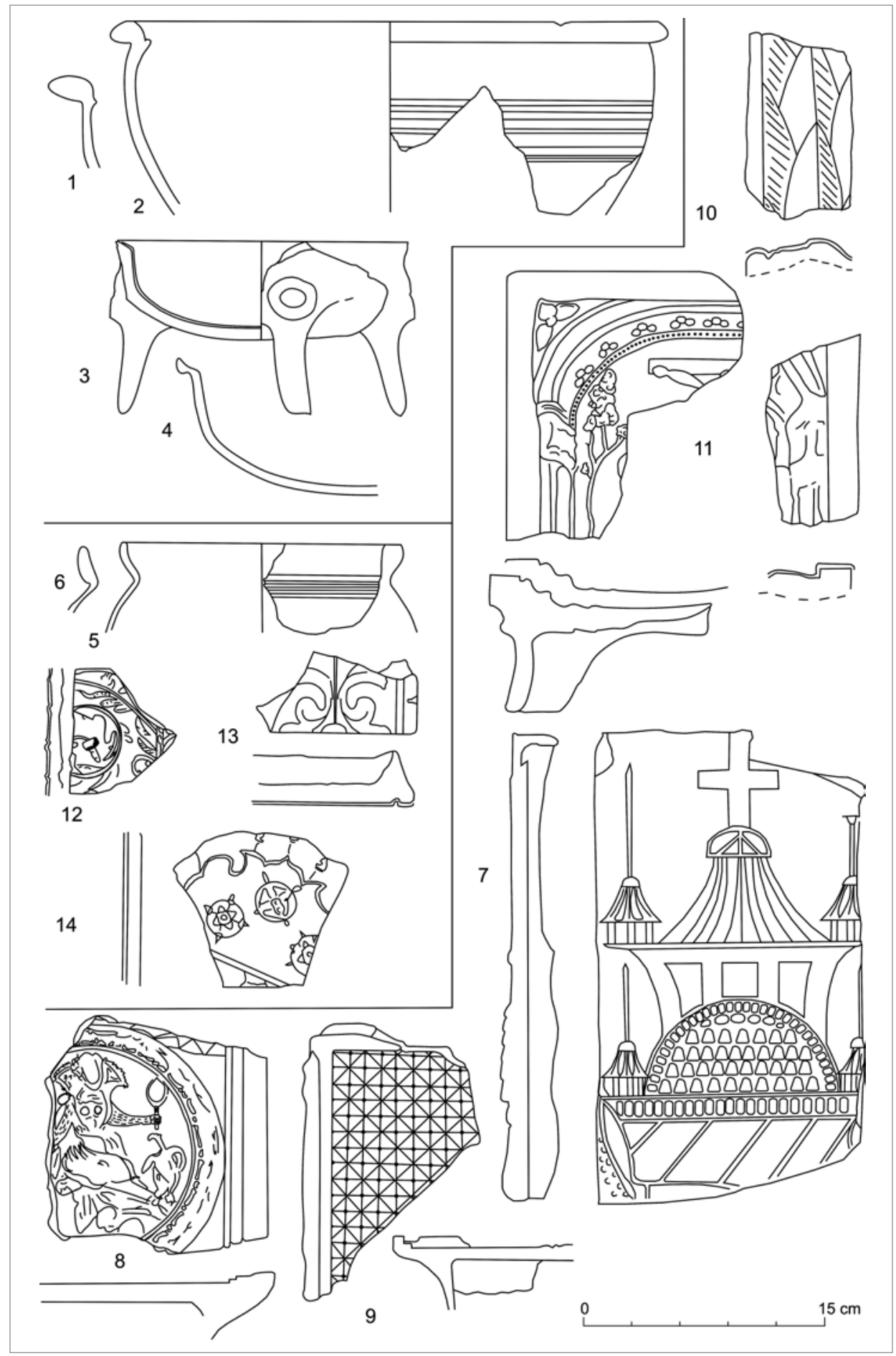

Tab. 2. Žilina, Ulica J. M. Hurbana. Výber keramiky a kachlíc z obranných priekop. Kresba S. Španihel.

Taf. 2. Žilina, Straße J. M. Hurbana. Keramik- und Kachelauswahl aus den Verteidigungsgräben. Zeichnung S. Španihel. 
Jednou z príbuzných vrstiev uloženiny 140 je stratigrafická jednotka 137 (obr. 6, 7). Zloženie keramických tried je podobné s vrstvou 129 , rovnako ako typologická skladba, v ktorej však narastá zastúpenie mís a trojnožiek. Zvýšil sa i percentuálny počet úch na vyšších hrncovitých nádobách.

Vo výzdobe, stále sa variačne rozhojňujúcej, prevládajú rôzne typy ryhovania a žliabkovania. Sekunduje im dekorácia radielkom. D̆alším okrasným prvkom sú vrypy a objavuje sa i pretláčanie zdobených okrajov u mís. Aj v tejto vrstve sa objavuje glazúra, a to na vnútorných stranách niektorých trojnožiek.

Okraje sú najmä von vyklonené, zjednodušené zosilnené typy, široko rozšírené, analógie poznáme najmä z Lietavy (Španihel 2014a, 98, obr. 2:3,4), príležitostne sa objaví vyhnuté zaoblené okružie, v príspevku spomínané už niekol'kokrát. Špecifické previsnuté, často zhrubnuté okraje (tab. 2:1,2) mís-perníc s vnútornou lištou sú známe od konca 15. storočia, ale prežívajú až do 18. storočia. Analógie pochádzajú z blízkeho okolia, prípadne regiónu, napríklad z Kaplnky Božieho tela (Španihel 2014, 171, obr. 7:5) či Radničnej ulice (Šedo 1975, obr. 89:1; obe lokality v Žiline), prípadne z hradu Strečno (Šedo 1975b, obr. 87:5), ale poznáme i vzdialenejšie obmeny, napríklad zo sliezskych Gliwic (Zdaniewicz 2012, 96, Fig. 90:b, 91: g), kde sú tiež datované iba približne do 16.-18. storočia.

Trojnožky sú skôr nižšie a širšie, miskovitého polgul'ovitého tvaru s dutou, najčastejšie otvorenou rukovätou (tab. 2:3). Jediný dochovaný okraj (tab. 2:4) je podrezaný vyhnutý variant s vnútorným preliačením a má paralelný nález z výskumu pivnice Mestského úradu v Kysuckom Novom Meste (Španihel 2014, 170, obr. 6:2), ktorej zásyp je datovaný do rozmedzia 16.-18. storočia. Pri dnách je pomer zrezaných a podsypaných kusov vyvážený.

Vrstvy zo spodnej časti vel'kej novovekej priekopy obsahujú len malé množstvo keramického materiálu. V zásypových vrstvách 116 a 108 (obr. 5,6) boli nájdené iba oxidačne vypálené nádoby, prevažne z keramickej triedy 3 , s minimálnou rytou výzdobou, ktorej funkciu prebrala rôznofarebná glazúra aplikovaná na vnútorných i vonkajších stenách nádob. Vel'ká čast' materiálu je neurčitel'ná, rozpoznatel'ný je najmä tanier. Medzi okrajmi prevažujú rôzne von vyklonené formy, objaví sa i okružie. Oba typy v rôznych formách už boli v článku spomenuté. Ostatné varianty, zväčša jednoduché vysoké kalichovité tvary (tab. 2:5, 6), sú známe napríklad zo sliezskych Gliwic (Zdaniewicz 2012, 95, Fig. 90: m, n), kde sú rámcovo datované do 16.-18. storočia. Žilinské exempláre sú však skoro o polovicu vyššie, čo by mohlo svedčit’ o ich mladšom pôvode v opozícii k sliezskym kusom. Dná nesú už len známky zrezávania z rýchlo rotujúceho kruhu.

V súbore sú i drobné zlomky kachlíc so štylizovaným rastlinným motívom. Ostatné fragmenty kachlíc pochádzajú zo stratigrafických jednotiek 108, 116 a 117 (tab. 2:12, 13, 14). Všeobecne ide najmä o silne štylizované rastlinné motívy mozaikovitého charakteru. Avšak s výnimkou kachlice, na ktorej sa dajú rozoznat' štylizované l'alie a medailóniky pripomínajúce ružu, sú tieto úlomky pochádzajúce takmer bez výnimky z čelných vyhrievacích stien vel'mi malé a na niektorých exemplároch sa nedá rozpoznat' ani typ výzdoby.

\section{Záver}

Keramika pochádzajúca z tohto výskumu patrí medzi bežnú regionálnu produkciu oblasti s farebným črepom. Najpočetnejšou nádobou počas celého skúmaného obdobia je hrniec, ktorý je s postupujúcim časom vybavený čoraz častejšie uchom. Ďalej sa vyskytujú jednoduché džbány hrncovitého charakteru a tzv. gotické poháre. V mladších vrstvách narastá počet trojnožiek, ku ktorým sa pripája stolová keramika, ktorú reprezentujú najmä široko roztvorené misy a taniere rôznych typov. Materiál, z ktorého bola žilinská keramika vyrábaná, je v drvivej väčšine miestneho pôvodu, oranžového až hnedého sfarbenia, čo je klasickým prejavom hlín karpatského oblúka. Rovnako tvarové i výzdobné prvky sú bežné pre spomínaný región, avšak sú tu badatel'né kontakty najmä so severozápadnými oblast’ami. Ide o región severomoravského výrobného okruhu a o širšie okolie Wrocławi, čo korešponduje s pohybom v priesmykoch prihraničných hôr i dial'kovou cestou do Sliezska, ktorá prechádzala v danej dobe Žilinskou kotlinou a Kysucami. 
Zaujímavým je súbor kachlíc, ku ktorým bolo potrebné nájst' vhodné analógie v relatívne d’alekom Nemecku a Mad’arsku. Je možné, že sa ich tvorcovia inšpirovali v zahraničí, no vzhl'adom na hrubost' záverečného prevedenia akiste nejde o dovoz, ale najskôr o produkt miestnej výroby.

Keramika z vrstvy 135 predstavuje vrcholnostredovekú produkciu regiónu. Nižšie súdkovité tvary hrncovitých nádob vychádzajúce $\mathrm{z}$ ranostredovekej tradície, sprevádzané hrubými pokusmi o redukčne vypal'ovanú keramiku kolonizačného pôvodu (poháre, zvoncovité pokrievky), sú vyrábané obtáčaním, o čom svedčí i hrubá a asymetrická výzdoba v podobe vlnoviek a rýh, ktoré sú okrem iného dôsledkom pomalého a nepravidelného otáčania hrnčiarskeho kruhu. Zohl'adnením tohto rozboru môžeme predpokladat' vznik (či skôr samotnú existenciu) stredovekej priekopy približne $\mathrm{v}$ polovici 14 . storočia.

Naopak, zániková vrstva 140 už reprezentuje rozvinutú hrnčiarsku výrobu mestského charakteru na rozhraní neskorého stredoveku a raného novoveku. Široká škála výrobkov obsahuje všetky dobové typy keramiky. Z úžitkovej keramiky je to vyšší amforovitý hrniec s uchom s jednoduchým vykloneným okrajom, trojnožky s otvorenou i zatvorenou rúčkou, esovito tvarované zvoncovité pokrievky, džbán s flaškovitým ústím i široko roztvorené tanierovité tvary, naopak už absentujú hrubé misy-pernice a poháre. Bohatá mechanická stredoveká výzdoba degraduje na niekol'ko rýh najčastejšie na pleci nádoby. Vyskytujú sa prvé čiastočne glazované nádoby, no za výzdobu sa dá glazúra považovat' iba v prípade importovaného gul'ovitého džbánu. Kachliarska produkcia predstavuje pestrú zmes gotických a renesančných motívov, na jednej strane reprezentovanými priečelím chrámu a na druhej personifikáciou Pýchy. Podla nálezov z tejto stratigrafickej jednotky i sprievodnej vrstvy 137 začína zánik priekopy začiatkom či v prvej polovici 17. storočia.

Vrcholnostredoveké nálezy pochádzajúce zo spodnej časti staršej priekopy jasne poukazujú na fakt, že priekopa existovala najneskôr na začiatku druhej polovice 14. storočia. Daný časový horizont pravdepodobne reprezentuje obdobie krátko po príchode nemeckých kolonistov a teda rané formovanie stredovekého mesta, výrazne podporované králom Karolom I. Róbertom z Anjou, ktorý mestu udel'uje rôzne privilégiá a oslobodzuje ho od platenia daní. Písomné pramene zo 14. storočia však nespomínajú žiadne opevnenie mesta, s výnimkou hradu. Prvý písomne doložený pokus o vybudovanie hradieb pochádza až z roku 1405, d’alší z roku 1474, no ani v 16. storočí hradby nestáli a prvé nešpecifikované opevnenie sa spomína až v roku 1620. Avšak, na základe keramických nálezov predpokladáme existenciu stredovekej priekopy v období minimálne od polovice 14. storočia až na prelom 16. a 17. storočia. Pôvodné teleso vrcholnostredovekej priekopy pravdepodobne získalo v prvej polovici 15 . storočia nový vzhl'ad, čo môže dokladat' tvar uloženiny 129 (obr. 5). Priekopa sa síce stala plytšou, ale bola rozšírená. Na prelome 16. a 17. storočia sa začína priekopa zapíňat' zásypovými vrstvami 137 a 140, ktoré reprezentujú svojimi nálezovými celkami práve obdobie okolo roku 1600 . Vd’aka tomuto zasypaniu sa priekopa stala nefunkčnou a pravdepodobne v krátkej dobe bola zahrnutá masívnymi vyrovnávacími vrstvami, ktoré sú v rôznych sondách odlišné. Bohužial', tieto vrstvy neobsahujú prakticky žiadny chronologicky citlivý materiál; ojedinele sa objavujú nevýrazné fragmenty stavebnej keramiky.

Písomné pramene sa teda najskôr zamerali na otázku kamenných hradieb a samostatnú priekopu, ktorá očividne nepredstavovala „obvyklé“ opevnenie mesta danej úrovne, ako sa spomína v príkaze Žigmunda Luxemburského, ignorovali.

Nálezy zo spodnej časti vel'kej novovekej priekopy, z vrstiev 108 a 116, sú už typickými výrobkami raného novoveku - silne homogenizovaná keramická masa, minimalistická mechanická výzdoba reprezentovaná jednou či dvoma ryhami na hrdle nádoby, najčastejšie na vysokom amforovitom hrnci, výrazné vyžívanie glazúr a farebných hliniek najmä na plytkých tanierovitých tvaroch a silne štylizované geometricko-rastlinné motívy komorových kachlíc.

Rovnako ako v stredovekej priekope, aj v tej vel'kej novovekej najstaršia uloženina predstavujúca obdobie prvotného využívania priekopy neobsahuje relevantný keramický materiál. Vrstvy 108 a 116 sú datovatel'né po polovici 17. storočia, čiže novoveká priekopa musela existovat' 
už v prvej polovici tohto storočia, takže môžeme predpokladat', že vnikla, ak nie ihned' po zasypaní stredovekej priekopy a vyrovnaní terénu, tak vo vel'mi krátkom čase po tejto udalosti. Jej zánik (nie stratu funkčnosti, ktorá určite nastala skôr) predpokladáme len na základe nepriamej písomnej zmienky najneskôr do roku 1848, nakol'ko vrchné zásypové vrstvy neobsahujú prakticky žiaden materiál vhodný pre datovanie. Obdobne datujeme do rovnakého obdobia i menšiu novovekú priekopu.

Výskum na Ulici J. M. Hurbana predstavuje výraznú zmenu v poznaní historického žilinského opevnenia. Okrem toho, že predstavuje najväčšiu preskúmanú plochu so vzt’ahom k problematike mestskej fortifikácie, je jediným miestom $\mathrm{v}$ historickom centre, kde bolo zachytených viac priekop, a to dokonca vo vzájomnom vzt’ahu. Vd’aka viacerým sondám je dokonca možné sledovat' i smerovanie priekop, čo pri predchádzajúcich výskumoch vzhl'adom na ich charakter nebolo reálne. Výskum poskytol taktiež relatívne početný keramický súbor, ktorého rozborom bolo možné spresnit' datovanie jednotlivých objektov a ich vzájomné vzt’ahy.

Vd’aka získaným informáciám sa môžeme vyjadrit' i k starším nálezom obranných priekop v Žiline. Rozsahom malé záchranné výskumy poskytli len širšie datovanie objektov, pričom vždy bola zachytená len jedna z priekop, pravdepodobne stredoveká. Až na výskum na ulici Na bráne č. 1 datoval autor J. Moravčík existenciu objektov obdobne ako my. Vo vyššie uvedenom prípade však nevieme posúdit', ktorá priekopa bola objavená. Vzhl'adom na datovanie vzniku do 15. storočia a zániku na prelome 17. a 18. storočia sa mohlo stat', že boli zachytené obe priekopy a mylne interpretované ako jedna.

Za najdôležitejšie poznatky považujeme $\mathrm{v}$ prvom rade rozpoznanie viacerých samostatných priekop a najmä rozlíšenie vrcholnostredovekej, ktorej vznik zachytáva obdobie formovania inštitualizovaného mesta.

Dôležitost' získaných informácií násobí nadväzujúci objav Žilinského hradu na vedlajšej parcele, takže je možné sledovat' archeologický vývoj celého severovýchodného okraja historického centra mesta, kde sú očividne v úzkom vzt’ahu tri významné žilinské lokality - obranné priekopy, hrad a farský kostol, čím sa potvrdzuje lokačná teória B. Puškárovej-Kovačevičovej $(1975,191)$, ktorá vysvetl'uje neobvyklú polohu Kostola Najsvätejšej Trojice vzhl’adom na dnešné Mariánske námestie jeho súvzt’ažnost’ou s hradom. Umiestnenie hradu očividne rešpektuje i vrcholnostredoveká priekopa, ktorá sa zo skúmanej plochy stáča smerom na juh a sleduje smer ulice Štôlňa, čiže sa lomí okolo veže a zdôrazňuje jej obrannú funkciu. Naopak, ranonovoveká priekopa už danú situáciu, pravdepodobne z dôvodu neexistencie hradu, nereflektuje a pokračuje priamo na východ, kde pravdepodobne ohrádza dobovú zástavbu.

Ako sa ukazuje, nález obranných priekop predstavuje dôležitý objav, ktorý objasnil a doplnil niekol'ko už dlhšie diskutovaných tém týkajúcich sa opevnenia mesta. Keramický súbor pochádzajúci z tohto výskumu rozšíril nepríliš početný stredoveký a ranonovoveký nálezový fond mesta, spresnil výsledky výskumu a ponúkol zaujímavú sondu do života miestnej populácie.

\section{Pramene}

HOŠŠO, J.-KOVÁČIK, P., 2005: Výskumná dokumentácia - „Podzemné záchytné parkovisko Žilina, Hurbanova ul.“-1. etapa záchranného archeologického výskumu, Bratislava - Brno.

HOŠŠO, J.-KOVÁČIK, P., 2006: Výskumná dokumentácia - „Podzemné záchytné parkovisko Žilina, Hurbanova ul.“-2. etapa záchranného archeologického výskumu, Bratislava - Brno.

MORAVČÍK, J., b. d.: Správa o výskume v Hodžovej ulici, Žilina.

\section{Literatúra}

BARTEKOVÁ, A., 2012: Studne s výdrevou z Trnavy - Hviezdoslavovej ulice - Holzgefasste Brunnen aus Trnava in der Hviezdoslavova-Straße, AH 37, 133-141. 
BIELICH, M.-VANGLOVÁ, T.-ZAJACOVÁ, B., 2012: Archeologický výskum v centre mesta Žilina Archäologische Ausgrabungen im Stadtzentrum von Žilina, ZbSNM Archeológia 22, 205-215.

BRYCH, V., 2004: Kachle doby gotické, renesanční a raně barokní. Výběrový katalog Národního muzea v Praze. Praha.

BŘEZINOVÁ, G.-SAMUEL, M. a kol., 2007: Tak čo, našli ste niečo? Svedectvo archeológie o minulosti Mostnej ulice v Nitre. Nitra.

GEBHARD, T., 1980: Kachelöfen, Mittelpunkt häuslichen Lebens. München.

HAZLBAUER, Z., 1998: Krása stř̌edověkých kamen. Odraz náboženských idejí v českém uměleckém řemesle - Die Schönheit der mittelaterlichen Kachelöfen. Reflexion reigiöser Ideen im böhmischen Kunstgewerbe. Praha.

HOŠŠO, J., 1981: Značky na keramike vrcholného stredoveku a novoveku zo Slovenska, Zborník Filozofickej fakulty Univerzity Komenského, Historica 32-33, 19-33.

- 1983: Prehlad vývoja stredovekej keramiky na Slovensku - Entwicklungsübersicht der mittelalterlichen Keramik in der Slowakei, AH 8, 215-231.

- 1988: Hrnčiarstvo, remeslo stredovekej dediny a mesta vo svetle archeologických prameňov. In: Historica 35-36, 105-139. Bratislava.

- 2004: Hranica medzi stredovekom a novovekom vo svetle archeologických nálezov keramiky - Die Grenze zwischen dem Mittelalter und der Neuzeit im Lichte der archäologischen Keramikfunde, AH 29, $569-580$.

HOŠŠO, J.-KÖNIG, T.-ŠUTEKOVÁ, J., 2011: Archeologický výskum na Ulici J. M. Hurbana v Žiline. In: AVANS 2011, 105-107. Nitra.

KOVÁČIK, P.-MORAVČÍK, J.-SCHÖN, M., 2008: Stredoveké opevnenie Žiliny. In: Forum Urbes Medii Aevi V. Městské fortifikace ve vrcholně středověkých městech stř̌ední Evropy, 86-95. Brno.

KRASNOKUTSKÁ, T., 2005: Středověké a novověké kachle z Opavy. Katalog nálezů z archeologických výzkumů - Medieval and Modern-Stove-Fitting in Opava. A Catalogue from Archaeological Excavations. Olomouc.

LIMISIEWICZ, A. a kol., 2002: Limisiewicz, A.-Piekalski, J.-Płonka, T.-Wiśniewski, A.-Wiśniewski, Z., Północna strona bloku śródrynkowego 1, Wratislavia Antiqua 5, 79-108.

LOSKOTOVÁ, I., 2008: Ornament na kachlích. In: Krása, která hřeje. Výběrový katalog gotických a renesančních kachlů Moravy a Slezska - Schönheit, die warmt. Gotische und renaissancezeitliche Kacheln aus Mähren und Schlesien (Menoušková, D.-Měřínský, Z., edd.), 139-155. Uherské Hradiště.

MÁCELOVÁ, M., 1986: Nález stredovekej keramiky v Benického dome v Banskej Bystrici - Ein Fund mittelalterlicher Keramik im Benický-Haus zu Banská Bystrica, AH 11, 481-487.

MARSINA, R., 1975: Žilina v období včasného a vrcholného feudalizmu. In: Halaj, D.-Marsina, R. a kol., Žilina, dejiny a prítomnost', 36-37. Martin.

- 2008: Žilina. In: Šüle, P.-Šüle ml., P., Encyklopédia miest a obcí Slovenska, 57. Lučenec.

- 2010: Žilina. In: Štefánik, M.-Lukačka, J. a kol., Lexikón stredovekých miest na Slovensku, 577-590. Bratislava.

MORAVČÍK, J., 1970: Najnovšie archeologické nálezy v okrese Žilina, Vlastivedný zborník Považia X, 5-26.

- 1975: Záchranný výskum v Žiline. In: AVANS 1975, 66. Nitra.

- 1980: Archeologické nálezy v Považskom Múzeu v rokoch 1971-1975, Vlastivedný zborník Považia XIV, $15-65$.

-2009: Podiel archeológie na osvetlení najstarších začiatkov Žiliny. In: Mrva, M.-Štanský, P., Mesto Žilina $\mathrm{v}$ rokoch 1208-2008, 13-24. Žilina.

PAJER, J., 1983: Počátky novověké keramiky ve Strážnici - Anfäge der Neuzeitlichen Keramik in Strážnice. Strážnice.

POLLA, B., 1971: Kežmarok (Výsledky historicko-archeologického výskumu). Bratislava.

- 1979: Bratislava - Západné suburbium (Výsledky archeologického výskumu). Bratislava.

PRIKRYL, L'. V.-ŠTANSKÝ, P., 1996: Chronológia vývoja mesta Žilina. Žilina.

PUŠKÁROVÁ-KOVAČEVIČOVÁ, B., 1975: Umelecko-historické pamiatky Žiliny. In: Halaj, D.-Marsina, R. a kol., Žilina, dejiny a prítomnost', 187-201. Martin.

REPKOVÁ, S., 2012: Interpretačné možnosti veže kruhového pôdorysu v centre Žiliny a jej pamiatková prezentácia - Interpretationsmöglichkeiten des Turms mit runden Fundamenten im Zentrum von Žilina und seine Präsentation als Denkmal, AH 37, 105-112.

STRAUSS, K., 1983: Die Kachelkunst des 15. bis 17. Jahrhunderts in europäischen Ländern, III. Teil. München. 
SZWED, R., 2004: Wczesnonowożytna ceramika naczyniowa z Ulicy Św. Antoniego we Wrocławiu, Wratislavia Antiqua 6, 331-381.

ŠEDO, O., 1975: Stredoveká keramika zo Žiliny (Radničnej ulice). In: AVANS 1975, 102. Nitra.

- 1975a: Nálezy stredovekej keramiky v Žiline. In: AVANS 1975, 101. Nitra.

- 1975b: Zist’ovací výskum na Strečnianskom hrade. In: AVANS 1975, 100. Nitra.

ŠPANIHEL, S., 2014: Stredoveká a novoveká keramika severozápadného Slovenska - Medieval and modern ceramic in north-western Slovakia, ŠZ 55, 141-179.

- 2014a: Stredoveká a novoveká keramika z Lietavského hradu. In: Hrad Lietava 2003-2013. Zborník z vedeckej konferencie 20.-21. júna 2014, 96-99. Zlín.

ZDANIEWICZ, R., 2012: The ceramic series from the town Square in Gliwice. In: Archaeology of a preindustrial town in Silesia. Case study Gliwice, Wratislavia Antiqua 16 (Michnik, M.-Piekalski, J., edd.), 82-101. Wrocław.

\section{Zusammenfassung}

\section{Keramikfunde aus Verteidigungsgräben der Stadt Žilina}

In den Jahren 2004 und 2005 wurde im historischen Kern der Stadt Žilina in der Straße J. M. Hurbana eine archäologische Rettungsgrabung durchgeführt, bei welcher grabenartige Gebilde entdeckt wurden. Hinsichtlich ihrer Form und Größe sowie wegen ihrer Lage und Orientierung im gesamten Innenbereich der Stadt nehmen wir an, dass es sich dabei um Verteidigungsgräben handelt. Bei der Grabung wurden zwei in Superposition liegende Objekte entdeckt, ein mittelalterlicher und ein frühneuzeitlicher Graben. Dem ging noch ein kleinerer, wahrscheinlich aus der Neuzeit stammender Graben voraus.

Das Problem der Stadtbefestigung von Žilina ist ein ständiger Diskussionsgegenstand. Die Stadt hatte keine Wehrmauer aus Stein, sondern war durch ein Befestigungssystem aus HolzLehm befestigt, das zwei Tore hatte, die wahrscheinlich jedoch aus Stein waren. Die erste indirekte Erwähnung einer Fortifikation erfolgte erst im Jahr 1620, und die erste Beschreibung stammt erst aus dem Jahr 1708, als der kaiserliche General L. Ebergényi ein aus Erdwällen, Holzpalisaden und Wassergräben bestehendes Verteidigungssystem errichten ließ.

Aus den entdeckten Objekten stammt eine relativ große Gruppe an Gebrauchs- und Ofenkeramik, deren Analyse der vorliegende Beitrag zum Thema hat.

Die ältesten Funde stammen aus der Nutzungszeit der mittelalterlichen Gräben und werden durch einen fassartigen Topf mit simsartigem Rand repräsentiert, der mit einer groben Wellenlinie und unregelmäßigen Rillen verziert ist. Zusammen mit einem massiven, sog. gotischen Becher und einem sehr groben, glockenförmigem Deckel stellen sie die traditionelle Produktion des Hochmittelalters dar. Die beiden anschließenden Verfüllungsschichten stellen eine relativ bunte Mischung spätmittelalterlicher Keramik dar. Der überwiegend darin vertretene Gefäßstyp sind im Oxidationsbrand gebrannte Töpfe mit Henkel, die zumeist einen Rand in Form eines runden, nach außen gebogenen Ringkragens, oder eine vereinfachte, nach außen gebogene Verstärkung aufweisen. Es kommen auch neue Gefäßarten vor wie Krüge, Tonschüsseln, Dreifüße und erste tellerartige Formen. Bei der in Oxidationsbrand hergestellten Keramik etabliert sich ein lineares Ritzdekor und bei der Reduktionskeramik die Rädchenverzierung. An der Innenseite der Gefäße erscheinen Glasuren.

Die letzte Verfüllungsschicht repräsentiert bereits den Übergang zur frühen Neuzeit. Deutlich vertreten sind flache tellerartige Formen und Ofenkeramik. Mechanische Verzierungen tun praktisch verschwinden, und in den Vordergrund gelangt ein aus Glasuren und Farberden bestehendes Dekor.

Die in den neuzeitlichen Gräben gemachte geringe Anzahl an Funden ermöglicht keine eingehendere Analyse, es überwiegen Töpfe und tellerartige Formen. Auf den Kacheln überwiegen stark stilisierte geometrische Pflanzenmotive. 
Anhand der gemachten Keramikfunde wird die Datierung der mittelalterlichen Gräben in den Zeitraum zwischen Mitte 14. bis erste Hälfte 17. Jahrhundert gelegt. Die Entstehung des großen neuzeitlichen Grabens wird der zweiten Hälfte des 17. Jahrhunderts zugeordnet, und aufgrund einer indirekten schriftlichen Erwähnung wird vermutet, dass er im Jahr 1848 beseitigt wurde. In die gleiche Zeit wird vorläufig auch der kleinere neuzeitliche Graben datiert.

Mgr. Samuel Španihel, Muzeum regionu Valašsko, Horní náměstí 2, 77501 Vsetín, Česká republika, spanihel@muzeumvalassko.cz 
